\title{
Dependency of Cytoplasmic Streaming on Intracellular ATP and $\mathrm{Mg}^{2+}$ Concentrations
}

\author{
Teruo Shimmen ${ }^{\mathrm{a}}$ \\ Department of Physiology, College of Medical Technology, Kansai, 3-1-69 \\ Inabaso, Amagasaki, Hyogo 660, Japan
}

\begin{abstract}
The rate of cytoplasmic streaming (v) was measured with reference to intracellular ATP and $\mathrm{Mg}^{2+}$ concentrations in tonoplast-free cells prepared by replacing the cell sap with EGTA-containing medium. The relation of $\mathrm{v}$ versus $[\mathrm{ATP}]_{\mathrm{i}}$ was a rectangular hyperbola. The ATP concentration for half saturation of $\mathrm{v}$ was $0.08 \mathrm{mM}$ in Nitella axillaris and $0.06 \mathrm{mM}$ in Chara corallina. From the results it is concluded that ATP is saturated for cytoplasmic streaming in normal cells, since the ATP concentration in the normal cytoplasm is about $0.5 \mathrm{mM}$. The relation between $\left[\mathrm{Mg}^{2+}\right]_{\mathrm{i}}$ and $\mathrm{v}$ differed from that between $[\mathrm{ATP}]_{\mathrm{i}}$ and $\mathrm{v}$. Stable cytoplasmic streaming was observed only when $\left[\mathrm{Mg}^{2+}\right]_{i}$ was equal to or higher than $[A T P]_{i}$. The inhibition of cytoplasmic streaming by depletion of ATP was completely reversible but that by depletion of $\mathrm{Mg}^{2+}$ was irreversible. ADP supported streaming. This may be explained by assuming that ATP was synthesized from ADP by the action of adenyl kinase in the cell.
\end{abstract}

The motive force of cytoplasmic streaming in Characeae cells is generated at the boundary between the stationary cortical gel layer and the mobile sol endoplasm (the sol-gel interface). The nature of the motive force is a shearing force produced by the organized gel surface and the sol phase (6). Bundles of microfilaments situated at the surface of the gel phase are assumed to be the component responsible for the generation of the motive force $(4,5,12)$. The filament binds rabbit muscle heavy meromyosin in arrowhead arrays, which indicates that the filaments are F-actin $(14,15,23)$. The relationship between the direction of the arrowheads and that of cytoplasmic streaming has also been clarified (9). Chen and Kamiya (2), and Kuroda and Kamiya (11) showed evidence suggesting that another (putative) component, myosin, is localized in the sol layer. Kato and Tonomura (8) purified myosin from Nitella flexillis.

The so-called cell model is a suitable system for determining the mechanism of cell motility; including muscle contraction (19), flagella and cilia movements $(1,13)$, amoeboid movement (18), movement of myxomycete plasmodium (7) and egg cleavage (10). Williamson (24) removed tonoplasts by perfusing the vacuole rapidly with a medium containing EGTA, a $\mathrm{Ca}^{2+}$-chelator. Tazawa, Kikuyama and Shimmen (21)

a) Present address: Department of Botany, Faculty of Science, University of Tokyo, Hongo, Tokyo 113, Japan

b) Abbreviations: ADP, adenosine-5'-diphosphoric acid; AMP, adenosine-5'-monophosphoric acid; ATP, adenosine-5'-triphosphoric acid; CyDTA, cyclohexanediamine-N,N, $N^{\prime}, N^{\prime}$-tetraacetic acid; EGTA, glycoletherdiamine-N,N, $N^{\prime}, N^{\prime}$-tetraacetic acid; PEP, phosphoenol pyruvic acid 
prepared tonoplast-free cells by replacing the cell sap with a medium containing EGTA. The tonoplast-free cell serves as a good model for studying cytoplasmic streaming, because the chemical composition around the sol-gel interface can be easily controlled. Williamson (24) and Tazawa et al., (21) showed that in tonoplastfree cells both ATP and $\mathrm{Mg}^{2+}$ are essential for streaming. In the Nitella internode the isolated endoplasmic drop whose surface membrane is removed (11) can also be a suitable model for studying the rotational movement of chloroplasts in the endoplasm.

Relationships between the rate of cytoplasmic streaming and the intracellular ATP and $\mathrm{Mg}^{2+}$ concentrations were studied using tonoplast-free cells.

\section{MATERIALS AND METHODS}

Nitella axillaris cultured in the laboratory was used except when noted. In the latter case Chara corallina cultured outdoors was used. Internodal cells were separated from neighboring cells and kept in tap water before use.

Compositions of the intracellular perfusion media are shown in Table 1. EGTA, $\mathrm{K}^{+}$, Tris-maleate and sorbitol were added to all perfusion media. The concentrations of ATP and $\mathrm{Mg}^{2+}$ were $0-1 \mathrm{mM}$ and $0-6 \mathrm{mM}$, respectively. The characterization of the perfusion medium was made by showing the concentrations of ATP and $\mathrm{Mg}^{2+}$. When the medium contained $1 \mathrm{mM}$ ATP and $6 \mathrm{mM} \mathrm{Mg}{ }^{2+}$, it was called $1 \mathrm{ATP} 6 \mathrm{Mg}$ medium. The osmotic value of the medium was adjusted to about the equivalent of $330 \mathrm{mM}$ sorbitol by controlling the sorbitol concentration. In some cases the ATP concentration in the medium was buffered by adding PEP and pyruvate kinase to the medium.

The method of producing tonoplast-free cells by vacuolar perfusion has been described elsewhere (21). After the cell sap was replaced with the perfusion medium, the cell was ligated at both opened ends with strips of polyester thread then bathed in artificial pond water (APW) containing $0.1 \mathrm{mM}$ each of $\mathrm{KCl}, \mathrm{NaCl}$ and $\mathrm{CaCl}_{2}$. Fig. 1 shows the internal morphologies of internodal cells. After the completion of vacuolar perfusion, there were no longer granules in the vacuole (Fig. 1b). After disintegration of the tonoplast, a large part of the endoplasm dispersed into the original vacuolar space and a smaller part moved along the chloroplast layer (Fig. 1c). The speed of a granule (v) was obtained by measuring the time needed to migrate a distance $25-200 \mu \mathrm{m}$. Speeds of at least the three fastest granules were measured and the average value was used as the rate of cytoplasmic streaming.

To control the intracellular ATP and $\mathrm{Mg}^{2+}$ concentrations, the second and third perfusions were carried out after the tonoplast had been removed by the first perfusion with the EGTAcontaining medium. In the first perfusion, replacement of the cell sap with artificial medium was confirmed by the effusion of cell sap which had been stained with neutral red beforehand

TABLE 1. COMPOSITIONS OF PERFUSION MEDIA

\begin{tabular}{lc} 
& concentration $(\mathrm{mM})$ \\
$\mathrm{ATP}$ & $0-1$ \\
$\mathrm{MgCl}_{2}$ & $0-6$ \\
$\mathrm{EGTA}$ & 5 \\
$\mathrm{~K}^{+}$ & $18-22$ \\
Tris-maleate & 5 \\
sorbitol & $275-290$ \\
\hline $\mathrm{pH}$ & 7 \\
\hline
\end{tabular}


Cell with tonoplast

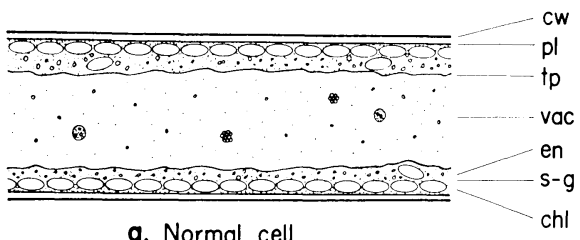

a. Normal cell

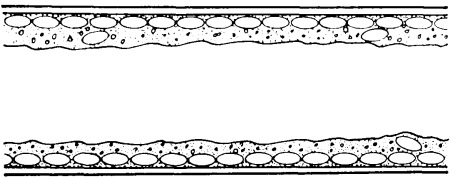

b. Vacuolar perfusion
Tonoplast-free cell

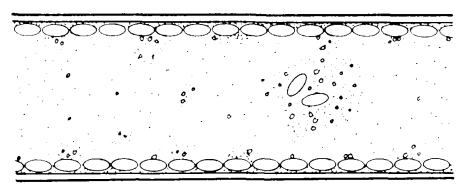

c. After Ist perfusion
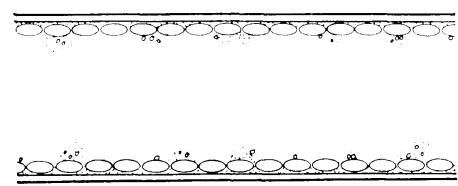

d. After 2 nd perfusion

Fig. 1. Longitudinal section of an internodal cell before and after disintegration of the tonoplast. cw; cell wall, pl; plasmalemma, tp; tonoplast, vac; vacuole, end; flowing endoplasm, s-g; sol-gel interface where the motive force is generated, chl; stationary chloroplast layer to which the actin bundles are anchored. a. Normal cell; before vacuolar perfusion, granules were observed in the vacuole. b. Vacuolar perfusion; after the cell sap had been replaced with artificial medium, there were no granules in the vacuole. c. After 1st perfusion; after disintegration of the tonoplast due to replacement of the cell sap with EGTA-containing medium, the original vacuolar space was filled with a mixture of sol endoplasm and the first perfusion medium. The endoplasm attached to the gel layer showed active streaming. d. After 2nd perfusion; a mixture of the sol components and the first perfusion medium which had filled the original vacuolar space was effused by this second perfusion. The endoplasm remaining in the cell moved along the chloroplast layer, when the second perfusion medium contained enough ATP and $\mathrm{Mg}^{2+}$.

(20). In the second or third perfusion the cell interior was perfused with an amount of medium about three times that of the cell volume. In the second perfusion internal fluid containing many endoplasmic fragments was effused and only a minor amount of sol components remained in the cell and moved along the files of chloroplasts (Fig. 1d). After the end of the second perfusion only $1 \%$ of the diffusible substances originally present in the cell remained unexchanged (17).

Experiments were conducted at room temperature $\left(18-25^{\circ} \mathrm{C}\right)$. Mean value of the rate of cytoplasmic streaming is shown with SEM and number of cells used (n).

\section{RESULTS}

The rate of cytoplasmic streaming $(v)$ in relation to the intracellular ATP concentration $\left([A T P]_{i}\right)$. The rate of cytoplasmic streaming for normal cells of $N$. axillaris was $100 \pm 3 \mu \mathrm{m} / \mathrm{sec}(\mathrm{n}=6)$ at $19^{\circ} \mathrm{C}$. To prepare tonoplast-free cells, the cell sap was replaced with OATP6Mg medium. After both open cell ends were closed, the cell was kept in APW. The streaming rate after distinegration of the tonoplast was $45 \pm 6 \mu \mathrm{m} / \mathrm{sec}$ $(n=8)$. The concentration of free $\mathrm{Ca}^{2+}\left(\left[\mathrm{Ca}^{2+}\right]_{i}\right)$ in the cell after disintegration of the tonoplast is estimated to be very low $\left(1.3 \times 10^{-8} \mathrm{M}, 21\right)$. A very low $\left[\mathrm{Ca}^{2+}\right]_{\mathrm{i}}$ does not affect cytoplasmic streaming but a high $\left[\mathrm{Ca}^{2+}\right]_{i}$ causes decreases in $\mathrm{v}(24)$. The tonoplast-free cells were perfused for the second time with media containing $6 \mathrm{mM} \mathrm{Mg}^{2+}$ 


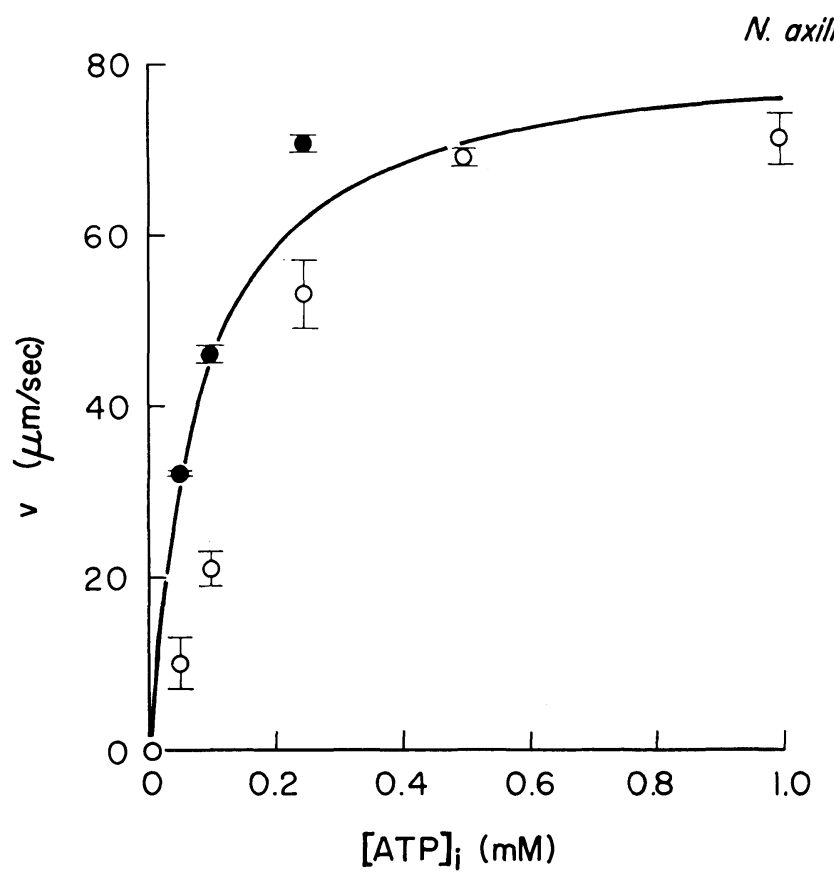

Fig. 2. The rate of cytoplasmic streaming (v) versus $\left.[\mathrm{ATP}]_{\mathrm{i}} . \bigcirc ; \mathrm{ATP}\right]_{\mathrm{i}}$ was not buffered. $\bullet$ $[A T P]_{i}$ was buffered by PEP and pyruvate kinase. Three to five cells were used for measurement of $v$ at each $[\mathrm{ATP}]_{\mathrm{i}}$. The average rate is shown with \pm SEM (vertical line). Measurement of $\mathrm{v}$ was carried out at $19 \pm 1^{\circ} \mathrm{C}$.

and various concentrations of ATP $(0-1 \mathrm{mM})$. The number of movinggranules decreased with time, because traveling granules often stopped at the ends of the cell. Consequently, $\mathrm{v}$ was measured soon after the cell was ligated at the end of the second perfusion. The relation between $[\mathrm{ATP}]_{\mathrm{i}}$ and $\mathrm{v}$ is shown in Fig. 2. Because physiological activities requiring ATP in tonoplast-free cells, such as cytoplasmic streaming $(21,24)$ and electrogenic pump(s) (16), continue, $[\mathrm{ATP}]_{\mathrm{i}}$ would decrease with time, if there is not sufficient synthesis of ATP after disintegration of the tonoplast. To avoid possible changes in ATP-concentration below $0.25 \mathrm{mM},[\mathrm{ATP}]_{i}$ was buffered with $1 \mathrm{mM}$ PEP and $1 \mathrm{mg} / \mathrm{ml}$ pyruvate kinase. PEP, itself, could not fuel streaming. At higher concentrations, 0.5 and $1.0 \mathrm{mM}$, the ATP concentration was not buffered, since at these concentrations ATP was saturated for streaming. The rate of streaming was increased by buffering $[\mathrm{ATP}]_{\mathrm{i}}$ (Fig. 2). The relation between $[\mathrm{ATP}]_{\mathrm{i}}$ and $\mathrm{v}$ was a rectangular hyperbola. $\mathrm{K}_{1 / 2}$, which is $[\mathrm{ATP}]_{\mathrm{i}}$ where $\mathrm{v}$ is half the maximum rate, was $0.08 \mathrm{mM}$.

In Chara corallina the $\mathrm{v}$ of cells containing $1 \mathrm{ATP} 6 \mathrm{Mg}$ medium was $60 \mu \mathrm{m} / \mathrm{sec}$ and $\mathrm{K}_{1 / 2}$ was $0.06 \mathrm{mM}$ at $19^{\circ} \mathrm{C}$ (data not shown).

The rate of cytoplasmic streaming in relation to the intracellular $\mathrm{Mg}^{2+}$ concentration $\left(\left[\mathrm{Mg}^{2+}\right]_{i}\right)$. The relation between $\left[\mathrm{Mg}^{2+}\right]_{\mathrm{i}}$ and $\mathrm{v}$ was investigated. After removal of the tonoplast by the first perfusion with $0 \mathrm{ATP} 6 \mathrm{Mg}$ medium, medium containing $1 \mathrm{mM}$ ATP and various concentrations of $\mathrm{MgCl}_{2}$ was introduced into the cell. [ATP $]_{i}$ was not buffered. The rate of cytoplasmic streaming was measured about one minute 


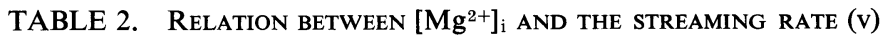
IN CELLS CONTAINING $1 \mathrm{mM}$ ATP

\begin{tabular}{ccccccc}
\hline 1ATP0Mg & 1ATP0.05Mg & 1ATP0.1Mg & $\begin{array}{c}\text { Medium } \\
\text { 1ATP0.25Mg }\end{array}$ & 1ATP0.5Mg & 1ATP1Mg & 1ATP6Mg \\
\hline 0 & 0 & 42 & $0^{*}$ & 34 & 59 & 80 \\
0 & 0 & 0 & 0 & 42 & 67 & 83 \\
0 & 0 & 0 & 1 & $0^{*}$ & 63 & 74 \\
& $0^{*}$ & 0 & 0 & 50 & & \\
& 20 & 0 & 0 & 0 & & \\
\hline 0 & 9 & 9 & 0 & 4 & & \\
\hline
\end{tabular}

* Moving granules were observed but v could not be measured, because granules stopped soon after microscopic observation was began. Experiments were done at $21 \pm 2^{\circ} \mathrm{C}$. $\mathrm{v}$ is shown in $\mu \mathrm{m} / \mathrm{sec}$.

after the end of perfusion. The relation between $\left[\mathrm{Mg}^{2+}\right]_{i}$ and $\mathrm{v}$ is shown in Table 2 . Between 0 and $0.25 \mathrm{mM}\left[\mathrm{Mg}^{2+}\right]_{\mathrm{i}}$, in most cells no moving granules were observed. At $0.5 \mathrm{mM}\left[\mathrm{Mg}^{2+}\right]_{\mathrm{i}}, \mathrm{v}$ varied significantly among cells. Some granules stopped soon after observation. At $1 \mathrm{mM}\left[\mathrm{Mg}^{2+}\right]_{\mathrm{i}}$, stable cytoplasmic streaming was observed (63 $\mu \mathrm{m} / \mathrm{sec})$. The rate increased when $\left[\mathrm{Mg}^{2+}\right]_{\mathrm{i}}$ was increased to $6 \mathrm{mM}$. Cytoplasmic streaming was observed even at an $\left[\mathrm{Mg}^{2+}\right]_{i}$ lower than $0.5 \mathrm{mM}$, when $[\mathrm{ATP}]_{i}$ was decreased to the same level as $\left[\mathrm{Mg}^{2+}\right]_{i}$ (Table 3).

The reversibility of cytoplasmic streaming for changes in $[A T P]_{i}$ or $\left[\mathrm{Mg}^{2+}\right]_{i}$. The recovery of $\mathrm{v}$ due to the introduction of ATP into ATP-depleted cells was tested (Table 4A). The rate of streaming in the tonoplast-free cell prepared by the first perfusion with $1 \mathrm{ATP} 6 \mathrm{Mg}$ medium was $87 \pm 5 \mu \mathrm{m} / \mathrm{sec}$. Variations in $\mathrm{v}$ among the cells (Table 4 ) seem to have resulted from uncontrolled room temperature $\left(18-25^{\circ} \mathrm{C}\right)$. The cell interior was perfused with 0ATP6Mg medium. The depletion of ATP resulted in the cessation of cytoplasmic streaming. When $1 \mathrm{ATP} 6 \mathrm{Mg}$ medium was reintroduced into the ATP-depleted cells, $v$ recovered to a level $(80 \pm 4 \mu \mathrm{m} / \mathrm{sec})$ which was nearly equal to the original rate.

The recovery of $\mathrm{v}$ due to the introduction of $\mathrm{Mg}^{2+}$ into $\mathrm{Mg}^{2+}$-depleted cells was also tested (Table 4B). When the cell interior was perfused with $1 \mathrm{ATP} 0 \mathrm{Mg}$ medium

TABLE 3. THE RATE OF CYTOPLASMiC STREAMING (v) IN CELLS CONTAINING ATP AND $\mathrm{Mg}^{2+}$ AT THE SAME CONCENTRATIONS

\begin{tabular}{cc}
\hline & Medium \\
$0.25 \mathrm{ATP} 0.25 \mathrm{Mg}$ & $0.5 \mathrm{ATP} 0.5 \mathrm{Mg}$ \\
\hline 42 & 43 \\
45 & 56 \\
40 & 48 \\
38 & \\
45 & \\
\hline $42 \pm 1$ & $49 \pm 4$
\end{tabular}

After disintegration of the tonoplast due to replacement of the cell sap with 0ATP6Mg medium, the cell interior was perfused with $0.25 \mathrm{ATP} 0.25 \mathrm{Mg}$ or $0.5 \mathrm{ATP} 0.5 \mathrm{Mg}$ medium. $[\mathrm{ATP}]_{\mathrm{i}}$ was not buffered. Experiments were done at $21 \pm 2^{\circ} \mathrm{C} . \mathrm{v}$ is shown in $\mu \mathrm{m} / \mathrm{sec}$. 
TABLE 4. REVERSIBILITY OF THE RATE OF CYTOPLASMIC STREAMING ( $\mathrm{v}$ in $\mu \mathrm{m} / \mathrm{sec}$ ) DUE TO CHANGES IN $[\mathrm{ATP}]_{\mathrm{i}}$ AND $\left[\mathrm{Mg}^{2+}\right]_{\mathrm{i}}$

A

\begin{tabular}{cccc} 
Cell No. & $\begin{array}{c}\text { Perfusion medium } \\
\text { First } \\
\text { 1ATP6Mg }\end{array}$ & $\begin{array}{c}\text { Second } \\
\text { 0ATP6Mg }\end{array}$ & $\begin{array}{c}\text { Third } \\
\text { 1ATP6Mg }\end{array}$ \\
\hline 1 & 71 & 0 & 63 \\
2 & 69 & 0 & 77 \\
3 & 95 & 0 & 83 \\
4 & 95 & 0 & 91 \\
5 & 91 & 0 & 87 \\
6 & 100 & 0 & 80 \\
\hline Average & $87 \pm 5$ & 0 & $80 \pm 4$ \\
\hline
\end{tabular}

$\mathrm{C}$

\begin{tabular}{|c|c|c|c|}
\hline \multicolumn{4}{|c|}{ Perfusion medium } \\
\hline Cell No. & $\begin{array}{c}\text { First } \\
\text { 1ATP6Mg }\end{array}$ & $\begin{array}{c}\text { Second } \\
\text { 0ATPOMg }\end{array}$ & $\begin{array}{c}\text { Third } \\
\text { 1ATP6Mg }\end{array}$ \\
\hline 1 & 一 & 0 & 11 \\
\hline 2 & 91 & 0 & 17 \\
\hline 3 & 95 & 0 & 20 \\
\hline 4 & 一 & 0 & 11 \\
\hline 5 & 80 & 0 & 0 \\
\hline 6 & 95 & 0 & 0 \\
\hline 7 & 80 & 0 & 26 \\
\hline Average & $88 \pm 3$ & 0 & $12 \pm 4$ \\
\hline
\end{tabular}

Experiments were done at $18-25^{\circ} \mathrm{C}$.
B

\begin{tabular}{cccc}
\hline \multicolumn{4}{c}{ Perfusion medium } \\
Cell No. & $\begin{array}{c}\text { First } \\
\text { 1ATP6Mg }\end{array}$ & $\begin{array}{c}\text { Second } \\
\text { 1ATP0Mg }\end{array}$ & $\begin{array}{c}\text { Third } \\
\text { 1ATP6Mg }\end{array}$ \\
\hline 1 & 61 & 0 & 0 \\
2 & 61 & 0 & 0 \\
3 & 91 & 0 & 0 \\
4 & 91 & 0 & 0 \\
5 & 93 & 0 & 0 \\
\hline Average & $79 \pm 8$ & 0 & 0 \\
\hline
\end{tabular}

D

\begin{tabular}{|c|c|c|c|}
\hline \multicolumn{4}{|c|}{ Perfusion medium } \\
\hline Cell No. & $\begin{array}{c}\text { First } \\
\text { 1ATP6Mg }\end{array}$ & $\begin{array}{c}\text { Second } \\
\text { 0ATPCyDTA }\end{array}$ & $\begin{array}{c}\text { Third } \\
\text { 1ATP6Mg }\end{array}$ \\
\hline 1 & 91 & - & 0 \\
\hline 2 & 95 & - & 0 \\
\hline 3 & 95 & - & 0 \\
\hline 4 & 95 & - & 0 \\
\hline Average & $94 \pm 1$ & 一 & 0 \\
\hline
\end{tabular}

after the tonoplast had been removed by replacing the cell sap with 1 ATP6Mg medium, no streaming was observed. Cytoplasmic streaming was not recovered by introducing $\mathrm{Mg}^{2+}$ into $\mathrm{Mg}^{2+}$-depleted cells by perfusion with $1 \mathrm{ATP} 6 \mathrm{Mg}$ medium. Cytoplasmic streaming, which had stopped after the second perfusion with 0ATP0Mg medium, recovered only slightly after the introduction of ATP and $\mathrm{Mg}^{2+}$ (Table 4C). Five minutes elapsed between the second and third perfusions.

$\left[\mathrm{Mg}^{2+}\right]_{\mathrm{i}}$ was severely lowered by CyDTA which combines strongly with both $\mathrm{Ca}^{2+}$ and $\mathrm{Mg}^{2+}$ (Table 4D). After disintegration of the tonoplast by the first perfusion with 1 ATP6Mg medium, the cell interior was perfused with 0ATPCyDTA medium containing $5 \mathrm{mM}$ CyDTA, $5 \mathrm{mM}$ Tris-maleate, $21 \mathrm{mM} \mathrm{KOH}$ and $305 \mathrm{mM}$ sorbitol (pH 7). The cell was kept on the perfusion bench (21) without closing the open cell ends after the finish of the second perfusion with 0ATPCyDTA medium. One minute after the end of the second perfusion, the cell interior was perfused with 1 ATP6Mg medium. Even though the period during which the cell was exposed to a very low $\left[\mathrm{Mg}^{2+}\right]_{\mathrm{i}}$ was short (one minute), cytoplasmic streaming did not recover with the introduction of $\mathrm{Mg}^{2+}$ into the cell (Table 4D).

Effects of other phosphorous compounds on cytoplasmic streaming. Effects of AMP, ADP, orthophosphate and pyrophosphate on cytoplasmic streaming were tested. After the tonoplast had been removed by replacing the cell sap with 0ATP6Mg medium, the cell interior was perfused with a medium containing $1 \mathrm{mM}$ of the test 


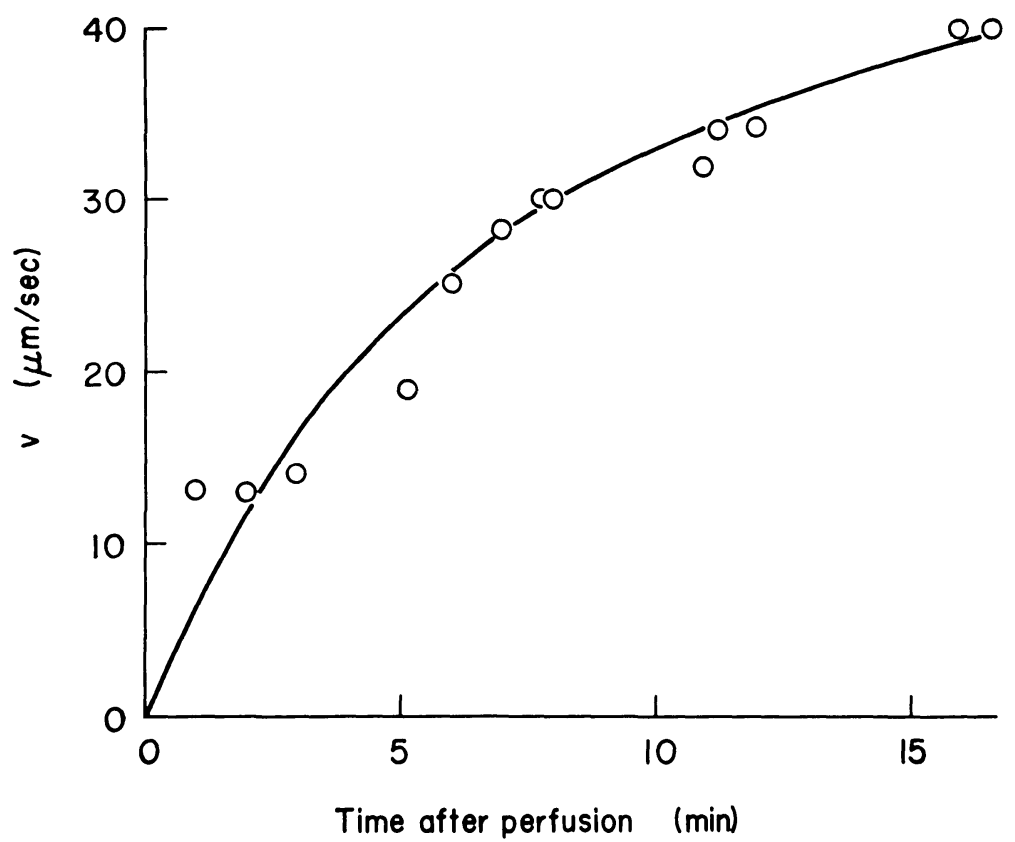

Fig. 3. Time course for the rate of cytoplasmic streaming (v) after the introduction of ADP into the tonoplast-free cell. Medium containing $1 \mathrm{mM}$ ADP and $6 \mathrm{mM} \mathrm{Mg}^{2+}$ was introduced into the cell after disintegration of the tonoplast caused by the first perfusion with 0ATP6Mg medium. $v$ was measured at $20^{\circ} \mathrm{C}$.

compound instead of $1 \mathrm{mM}$ ATP in 1ATP6Mg medium. AMP, orthophosphate and pyrophosphate could not support cytoplasmic streaming, but ADP could. A typical example is shown in Fig. 3. The measurement of $v$ was started about one minute after the end of perfusion with the ADP-containing medium. The rate was low at the beginning and increased with time.

\section{DISCUSSION}

The relation between $[\mathrm{ATP}]_{\mathrm{i}}$ and the rate of cytoplasmic streaming was a rectangular hyperbola. The value for $\mathrm{K}_{1 / 2}$ was $0.08 \mathrm{mM}$ in $N$. axillaris and $0.06 \mathrm{mM}$ in C. corallina. Since the ATP concentration in the cytoplasm of normal Characeae cells is around $0.5 \mathrm{mM}$ (3, Kikuyama, Hayama, Fujii and Tazawa, unpublished), we concluded that the $[\mathrm{ATP}]_{\mathrm{i}}$ in normal cells is saturated for the effect on cytoplasmic streaming.

The rate of streaming in the cell with 1 ATP6Mg medium was $69 \mu \mathrm{m} / \mathrm{sec}$ (Fig. 2), which is $69 \%$ of the normal rate $(100 \mu \mathrm{m} / \mathrm{sec})$. The decrease in the $\mathrm{K}^{+}$concentration to $1 / 5$ (22 $\mathrm{mM}$, Table 1$)$ the normal concentration in the cytoplasm $(112 \mathrm{mM}, 22)$ might cause a decrease in $\mathrm{v}$. However, even when the cell sap had been replaced with $1 \mathrm{ATP} 6 \mathrm{Mg}$ medium whose $\mathrm{K}^{+}$concentration had been increased to $100 \mathrm{mM}$ by adding $\mathrm{K}$-methane sulfonate, after the disintegration of the tonoplast $\mathrm{v}$ was $77 \%$ of the normal rate.

Because both ATP and $\mathrm{Mg}^{2+}$ are responsible for cytoplasmic streaming $(21,24)$, 
a rectangular hyperbola is expected between $\left[\mathrm{Mg}^{2+}\right]_{\mathrm{i}}$ and $\mathrm{v}$. However, the relation was not a hyperbola (Table 2). Cytoplasmic streaming was almost completely inhibited, when $\left[\mathrm{Mg}^{2+}\right]_{\mathrm{i}}$ was lower than $[\mathrm{ATP}]_{\mathrm{i}}$.

In contrast to the reversible inhibition of cytoplasmic streaming due to the depletion of ATP (Table 4A), the depletion of $\mathrm{Mg}^{2+}$ irreversibly inhibited cytoplasmic streaming (Table 4B). Because $\left[\mathrm{Mg}^{2+}\right]_{\mathrm{i}}$ was lowered by perfusing the cell with $1 \mathrm{ATP}$ $0 \mathrm{Mg}$ medium (Table 4B), the possibility is that free ATP, which is not in the form of $\mathrm{Mg} \cdot \mathrm{ATP}$, inhibits cytoplasmic streaming. If this is the case, then the inhibition of cytoplasmic streaming with $0 \mathrm{ATP} 0 \mathrm{Mg}$ medium containing no free ATP is reversible. However, only the partial recovery of cytoplasmic streaming was observed when $1 \mathrm{ATP} 6 \mathrm{Mg}$ medium was introduced into the cell containing $0 \mathrm{ATP} 0 \mathrm{Mg}$ medium (Table 4C). This suggests that this possibility is not valid and that the cause of the irreversible inhibition of streaming caused by $1 \mathrm{ATP} 0 \mathrm{Mg}$ medium is the depletion of $\mathrm{Mg}^{2+}$. The involvement of $\mathrm{Mg}^{2+}$ ions per se in cytoplasmic streaming is further supported by the fact that CyDTA, an extremely potent $\mathrm{Mg}^{2+}$-chelator, inhibited streaming completely in the absence of ATP (Table 4D). The deviation in the relationship between $\left[\mathrm{Mg}^{2+}\right]_{i}$ and $v$ from a rectangular hyperbola (Table 2) can be accounted for in terms of the depletion of free $\mathrm{Mg}^{2+}$ at an $\left[\mathrm{Mg}^{2+}\right]_{i}$ lower than the $[\mathrm{ATP}]_{\mathrm{i}}(1 \mathrm{mM})$. Williamson (24) also reported that motility requires a millimolar $\mathrm{Mg}^{2+}$ level but he did not examine the effect of free ATP. The necessity for free $\mathrm{Mg}^{2+}$ for streaming and the irreversible inhibition of streaming caused by the depletion of $\mathrm{Mg}^{2+}$ were demonstrated.

Although the mechanism for the irreversible inhibition of cytoplasmic streaming caused by the depletion of free $\mathrm{Mg}^{2+}$ is not clear, $\mathrm{Mg}^{2+}$ may have a role in maintaining some structure(s) necessary for streaming as well as a role as cofactor in the ATPase reaction. The fact that the inhibition of cytoplasmic streaming with medium lacking an $\mathrm{Mg}^{2+}$-chelator was only partially reversed by $1 \mathrm{ATP} 6 \mathrm{Mg}$ medium (Table 4C) suggests that the association of $\mathrm{Mg}^{2+}$ with the 'site' of a structure(s) responsible for the maintenance of cytoplasmic streaming is relatively weak.

Of the phosphorous comounds other than ATP, only ADP was effective (Fig. 3). This coincides with the results obtained by Williamson (24). The rate increased with time after intracellular perfusion with medium containing $1 \mathrm{mM}$ ADP and reached $40 \mu \mathrm{m} / \mathrm{sec}$ (Fig. 3). The increase in $\mathrm{v}$ with time is believed to result from the synthesis of ATP from ADP due to the action of adenyl kinase in the cell $(16,24)$. The ATP concentration in the cell 15 minutes after the introduction of ADP was calculated to be $0.074 \mathrm{mM}$ from Fig. 1 .

Acknowledgements. I wish to express my thanks to Professor Noburô Kamiya, the Institute for Basic Biology, Okazaki, and to Professor Masashi Tazawa, the University of Tokyo for their constructive criticisms of this manuscript.

\section{REFERENCES}

1. Brokaw, C.J. Movement of the flagella of Polytoma uvella. J. Exp. Biol. 40, 149-156, 1963

2. Chen, J.C.W. and N. KamiYA. Localization of myosin in the internodal cell of Nitella as suggested by differential treatment with N-ethylmaleimide. Cell Structure Function 1, 1-9, 1975

3. Hatano, S. and H. Nakajima. ATP content and ATP-dephosphorylating activity of Nitella. Ann. Rep. Sci. Works Fac. Sci. Osaka Univ. 11, 71-76, 1963

4. Kamitsubo, E. Motile protoplasmic fibrils in cells of Characeae. II. Linear fibrillar structure 
and its bearing on cytoplasmic streaming. Proc. Japan Acad. 42, 640-643, 1966

5. Kamitsubo, E. Motile protoplasmic fibrils in the cells of Characeae. Protoplasma 74, 53-70, 1972

6. Kamiya, N. and K. Kuroda. Velocity distribution of the protoplasmic streaming in Nitella cells. Bot. Mag. Tokyo 69, 543-554, 1956

7. Kamiya, N. and K. Kuroda. Movement of myxomycete plasmodium. I. A study of glycerinated models. Proc. Japan Acad. 41, 837-841, 1965.

8. Kato, T. and Y. Tonomura. Identification of myosin in Nitella flexilis. J. Biochem. 82, 777-782, 1977

9. Kersey, Y.M., P.K. Hepler, B.A. Palevitz and N.K. Wessells. Polarity of actin filaments in characean algae. Proc. Natl. Acad. Sci. USA. 73, 165-167, 1976

10. Kinoshita, S. and I. YazaKi. The behavior and localization of intracellular relaxing system during cleavage in the sea urchin egg. Exp. Cell Res. 47, 449-458, 1967

11. Kuroda, K. and N. KamiYa. Active movement of Nitella chloroplasts in vitro. Proc. Japan Acad. 51, 774-777, 1975

12. NaGAI, R. and L.I. Lebhan. Cytoplasmic microfilaments in streaming Nitella cells. J. Ultrastruct Res. 14, 571-589, 1966

13. NaItoh, Y. and H. Kaneko. Reactivated Triton-extracted models of Paramecium: Modification of ciliary movement by calcium ions. Science 176, 523-524, 1972

14. Palevitz, B.A., J.F. Ash and P.K. HePler. Actin in the green alga Nitella. Proc. Natl. Acad. Sci. USA. 71, 363-366, 1975

15. Palevitz, B.A. and P.K. Hepler. Identification of actin in situ at the ectoplasm-endoplasm interface of Nitella. Microfilament-chloroplast association. J. Cell Biol. 65, 29-38, 1975

16. Shimmen, T. and M. Tazawa. Control of membrane potential and excitability of Chara cells with ATP and $\mathrm{Mg}^{2+}$. J. Membrane Biol. 37, 167-192, 1977

17. Shimmen, T. and M. TAzawa. Intracellular chloride and potassium ions in relation to excitability of Chara membrane. (submitted to J. Membrane Biol.)

18. Simard-Duquesne, N. and P. Couillard. Ameboid movement. I. Reactivation of glycerinated models of Amoeba proteus with adenosine triphosphate. Exp. Cell Res. 28, 85-91, 1962

19. Szent-Györgi, A. Free-energy relations and contraction of muscle. Biol. Bull. 96, 140-161, 1949

20. TAZAwa, M. Studies on Nitella having artificial cell sap. I. Replacement of the cell sap with artificial solutions. Plant Cell Physiol. 5, 33-43, 1964

21. Tazawa, M., M. Kikuyama and T. Shimmen. Electric characteristics and cytoplasmic streaming of Characeae cells lacking tonoplast. Cell Structure Function 1, 165-176, 1974

22. Tazawa, M., U. Kishimoto and M. Kikuyama. Potassium, sodium and chloride in the protoplasm of Characeae. Plant Cell Physiol. 15, 103-110, 1976

23. Williamson, R.E. Actin in the alga Chara corallina. Nature (Lond.) 248, 801-802, 1974

24. Williamson, R.E. Cytoplasmic streaming in Chara: A cell model activated by ATP and inhibited by cytochalasin B. J. Cell Sci. 17, 655-668, 1975 